\title{
Pemohon Tanggung Jawab Negara Dalam Hukum Internasional (Studi Kritis Terhadap ILC Draft On State Responsibility 2001)
}

\section{Sefriani}

\begin{abstract}
Abstrak
Up to the present, the discussion of secondany rules or state responsibility law under International law is still on the debate of the international community. However, state responsibility can be claimed on the international relations when a state is disadvantaged by the other state, because of the violation of the obligations which raises from treaty, customary international law, or because of not fulfilled the international court decision.
\end{abstract}

\section{Pendahuluan}

Prinsip kedaulatan negara dalam hubungan internasional sangatlah dominan. Negara berdaulat yang satu tidak tunduk pada negara berdaulat yang lain. Negara mempunyai kedaulatan penuh atas orang, barang dan perbuatan yang ada di teritorialnya. Meskipun demikian, tidaklah berarti bahwa negara dapat menggunakan kedaulatan itu seenaknya sendiri. Hukum internasional telah mengatur bahwa di dalam kedaulatan terkait di dalamnya kewajiban untuk tidak menyalahgunakan kedaulatan tersebut. Karenanya, suatu negara dapat dimintai pertanggungjawaban untuk tindakan-tindakan atau kelalaiannya yang melawan hukum.
Dalam interaksinya satu sama lain amat besar kemungkinannya negara membuat kesalahan ataupun pelanggaran yang merugikan negara lain, disinilah muncul pertanggungjawaban negara tersebut.' Pertanggungjawaban negara dalam hukum internasional pada dasarnya dilatarbelakangi pemikiran bahwa tidak ada satupun negara yang dapat menikmati hak-haknya tanpa menghormati hak-hak negara lain. Setiap pelanggaran terhadap hak negara lain menyebabkan negara tersebut wajib untuk memperbaikinya atau dengan kata lain mempertanggungjawabkannya. ${ }^{2} \mathrm{Hal}$ ini sebenarnya merupakan hal yang biasa dalam sistem

"Mohamad Burhan Tsani, Hukum dan Hubungan Internasional, Liberty, Yogyakarta, Cetakan Pertama,1990, him. 47

${ }^{2}$ Hingorani, Modem Intemational Law, edisi ke-2, 1984, hlm.241, sebagaimana dikutip oleh HualaAdoll, AspekAspek Negara Dalam Hukum Internasional, Rajawali Pers, Jakarta, Cetakan Pertama, 1991, hlm. 173 
hukum dimana pelanggaran terhadap kewajiban yang mengikat secara hukum akan menimbulkan tanggung jawab bagi pelanggarnya. $^{3}$

Dalam hukum internasional dikenal adanya dua macam aturan, primary rules dan secondary rules. Primary rules adalah seperangkat aturan yang mendefinisikan hak dan kewajiban negara yang tertuang dalam bentuk traktat, hukum kebiasaan atau intrumen lainnya. Adapun secondary rules adalah, seperangkat aturan yang mendefinisikan bagaimana dan apa akibat hukum apabila primary rules itu dilanggar oleh negara. Secondary rules inilah yang disebut hukum tanggung jawab negara (the law of state responsibilty). ${ }^{4}$

Sampai saat ini pembahasan mengenai secondary rules atau hukum tanggung jawab negara dalam hukum internasional sebagaimana dimaksud di atas masih sangat membingungkan. Hal ini dikarenakan belum adanya secondary rules yang mapan. ${ }^{5}$ Hukum tanggung jawab negara dikembangkan melalui hukum kebiasaan yang muncul dari praktek negaranegara, pendapat para pakar, juga putusan pengadilan internasional. 6 Di satu sisi para pakar hukum intemasional mengakui bahwa tanggung jawab negara merupakan suatu prinsip fundamental dalam hukum internasional, namun di sisi lain mereka juga mengakui bahwa hukum tanggung jawab negara masih dalam taraf menemukan konsepnya dan masih dalam proses perkembangan. Konsekuensinya, pembahasan terhadapnya dewasa ini masih sangat membingungkan. Umumnya para pakar hukum internasional hanya mengemukakan karakterisitik timbulnya tanggung jawab negara seperti halnya?:

1. adanya suatu kewajiban hukum internasional yang berlaku antara dua negara tertentu

2. adanya suatu perbuatan atau kelalaian yang melanggar kewajiban hukum internasional tersebut yang melahirkan tanggung jawab negara

3. adanya kerusakan atau kerugian sebagai akibat adanya tindakan yang melanggar hukum atau kelalaian

Meskipun belum pernah mendapat kesepakatan secara universal karakteristik di atas banyak diikuti dalam hukum internasional klasik. Dengan demikian tanggung jawab negara hanya bisa dituntut dalam hubungan internasional (antar negara) ketika ada satu negara yang dirugikan oleh negara lain akibat pelanggaran kewajiban yang muncul dari treaty, hukum kebiasaan internasional, atau akibat tidak memenuhi kewajiban yang muncul dari putusan pengadilan. ${ }^{8}$

Akibat belum mapannya secondary rules hukum tanggung jawab negara banyak

${ }^{3}$ Dixon, Martin, Textbook on International Law, Blackstone Press Limited, fourt edition, 2000, hIm. 231

4Mohamad Mova Al'Afghani, 'Kewajiban Swedia untuk Melakukan due Diligence Terhadap Permasalahan Hasan Tiro", makalah pada workshop on International Legal Process, Hotel lbis ,25-26 Juli 2003 , http// www.theceli.com/berita/detailphp?tipe=a\&news=B2, diakses 5 Maret2004

${ }^{5}$ Shaw, M.N, International Law, Grotius Publication, third edition, 1991, hlm.482

${ }^{6}$ Putusan-putusan pengadilan yang banyak memberikan pengaruh pada perkembangan hukum tanggung jawab negara antara lain Military and Paramilitary activities in andagainst Nicaragua Case (Nicaragua v USA) ICJ, 1986, Barcelona Traction Light Case, Martin, Dixon, loc.cit

${ }^{7}$ Shaw; M.N, loc.cit .

8Dixon, Martin, op.cit, him. 232 
permasalahan yang belum pernah terselesaikan Salah satu permasalahan yang masih terus diperdebatkan selama puluhan tahun adalah siapa yang dapat meminta pertanggungjawaban negara bila ada pelanggaran terhadap hukum internasional. Hukum internasional klasik selama ini cenderung sangat membatasi ruang lingkup tanggung jawab negara, subyeknya hanya negara, harus dalam kerangka hubungan antar negara atau bilateral. Di samping itu, hukum tanggung jawab negara juga dibatasi oleh prinsip teritorial, imunitas, yurisdiksi negara, kedaulatan negara, serta prinsip non intervensi. Pembatasan-pembatasan semacam ini dalam praktek terbukti sudah tidak memenuhi kebutuhan lagi, terlebih setelah makin banyaknya aktor-aktor non-negara dalam hubungan internasional, seperti non-government organization (NGO), individu, bahkan perusahaan-perusahaan transnasional.

Berkaitan dengan permasalahan di atas pada Nopember 2001 International Law Commission (ILC), berhasil mengadopsi draft mengenai tanggung jawab negara (Draft articles on Responsibilty of States for internationally Wrongful Acts). Draft ini saat ini merupakan draft terbaru yang diadopsi ILC untuk menjawab berbagai perkembangan yang terjadi dalam hukum internasional dan merupakan revisi dari draft-draft sebelumnya. Draft ini dinilai banyak pihak membawa perkembangan baru (progressive development) hukum tanggung jawab negara dalam hukum internasional Meskipun masih benwujud draft, sebenarnya isinya tidak lain dari praktek kebiasaan atau prinsip-prinsip hukum internasional yang telah diterima masyarakat internasional. Dengan demikian tidaklah mengherankan bilamana draft-draft ILC sebelumnya tentang tanggung jawab negara selama ini juga cukup punya pengaruh kuat, terbukti dengan seringnya dijadikan rujukan baik dalam berbagai literatur hukum internasional juga berbagai putusan pengadilan baik nasional maupun internasional.

Berkaitan dengan keberadaan draft 2001 tersebut makalah ini berupaya memaparkan perkembangan baru yang ada dalam draft tersebut khususnya menyangkut siapa yang dapat meminta atau memohon tanggung jawab negara dalam hukum internasional.

\section{Tanggung jawab negara dalam hukum internasional klasik}

Masalah siapa yang dapat meminta atau -menuntut pertanggungjawaban negara sebenarnya sudah menjadi perdebatan para pakar hukum internasional sejak abad lampau. Perbedaan pendapat antara pendapat bahwa hanya negara yang dirugikan langsunglah (direct injury) yang dapat menuntut serta pendapat lain bahwa semua negara atau masyarakat internasional (international society) dapat menuntut pertanggungjawaban pada negara yang melanggar hukum internasional tidak pernah berakhir dengan memuaskan sehingga menimbulkan ketidakkonsistenan atau keragaman dalam praktek penerapannya.

Perdebatan mengenai hal ini yang paling terkenal adalah perbedaan pandangan antara dua pakar hukum terkenal dari Italia yaitu Dionisio Anzilotti dan Roberto Ago. Apabila Anzilotti tidak membuat tingkatan terhadap pelanggaran hukum internasional maka Ago membedakannya menjadi delik (delicts) dan crimes dimana crimes dipandang sebagai pelanggaran yang lebih serius daripada delik. Anzilotti berpendapat bahwa tanggung jawab negara hanya timbul dalam hubungan bilateral 
negara, adapun menurut Ago terhadap kejahatan tertentu masyarakat internasional secara keselunuhan dapat meminta pertanggungjawaban pada negara pelanggar hukum internasional. Perbedaan ini muncul karena Anzilotti yang positivist berapandangan bahwa timbulnya tanggung jawab adalah dari suafu pelanggaran terhadap kewajiban yang mengikat antara dua pihak. Adapun Ago yang mewakili aliran hukum alam berpendapat bahwa kepentingan masyarakat internasional (international community interest) yang dilanggar dapat menimbulkan tanggung jawab negara. ${ }^{9}$

Dalam berbagai putusan pengadilan baik nasional maupun internasional, bahkan dalam draft ILC yang lama tentang tanggung jawab negara, pendapat Anzilotti lebih dominan. ${ }^{10}$ Demikianlah, dalam hukum internasional klasik hanya pelanggaran hukum internasional dari negara satu terhadap yang lain yang dapat menimbulkan tuntutan pertanggungjawaban untuk pemulihan terhadap kerugian yang diderita dan bukan sekedar pelanggaran kepentingan semata. Disamping itu hanya tindakan oleh negara, bukan tindakan oleh individu yang dapat menimbulkan pertanggungjawaban dalam hukum intemasional. Hukum intemasional klasik berpandangan sempit membatasi subyek hanya pada negara yang bertanggung jawab terhadap warga asing di negaranya." Pandangan tersebut menurut Edith Browns Weiss amat sangat wajar mengingat pasca perdamaian Westphalia 350 tahun yang lalu, negara adalah aktor utama dalam hukum dan hubungan internasional. ${ }^{12}$

Berdasarkan pembatasan-pembatasan dan karakteristik ${ }^{13}$ yang diberikan para pakar hukum internasional, selama puluhan tahun pertanggungjawaban negara hanya timbul dalam hubungan internasional, yaitu ketika ada negara lain yang dirugikan secara langsung. Contoh yang dapat dikemukakan antara lain ditolaknya tuntutan New Zealand dan Australia oleh Mahkamah Internasional dalam kasus percobaan nuklir oleh Perancis di laut lepas tahun 1974 dengan alasan kedua negara tidak mempunyai legal standing tidak dirugikan secara langsung, apalagi penduduk Polynesia, yang terdekat dengan lokasi percobaan tersebut tidak mengajukan tuntutan. Selama puluhan tahun juga kedaulatan negara (state sovereignity) digunakan sebagai tameng untuk tindakan-tindakan opresif negara. Kejadiankejadian di wilayah suatu negara dipandang sebagai masalah internal (internal matter) ${ }^{14}$. Perlakuan buruk negara terhadap warganya sendiri tidak menimbulkan pertanggungjawaban internasional. Negara lain tidak mempunyai

${ }^{9}$ Georg Nolte, "From Dioniso Anzillotti to Roberto Ago: The Classical Intemational Law of State Responsibility and the Traditional Primacy of a Bilateral Conception of Inter-state Relations ${ }^{n}$, dalam European Journal of International Law (EJIL) 2002, Vol. 13 No.5, hlm. 1083-1084

${ }^{10} \mathrm{lbid}$, hlm.1084-1086

11Daniel.Bodansky and John R Crook, "Symposium The ILC'S State Responsibility Article ;Introduction and Overview", dalam American Journal of Intemational Law (AJIL), Vol 96, 2002, hlm 776

${ }^{12}$ Edith Browns Weiss," Invoking State Responsibilty in the Twenty-First Centuries", dalam American Journal of International Law (AJIL), Vol. 96, 2002, hIm.798

${ }^{13}$ supra no. 5

${ }^{14}$ Mark Gibney, Katarina Tomasevski and Jens Vedsted-Hansen, "Transnasional State Responsibility for Violation of Human Rights", dalam Harvard Human Rights Journal, Vol 12, Spring 1999, hlm.3 
legal standing untuk minta pertanggungjawaban negara tersebut karena mereka tidak dirugikan. Hal ini juga sejalan dengan prinsip non-intervensi dalam hukum internasional, bahwa negara dilarang ikut campur terhadap urusan dalam negeri negara lain.

Masih dalam kaitannya dengan teritorial, masing-masing negara hanya bertanggung jawab terhadap pelanggaran HAM yang terjadi di teritorialnya. Amat sulit meminta tanggung jawab negara berkaitan dengan pelanggaran HAM yang terjadi di negara lain dimana sebenarnya ada keterlibatan negara pertama dari segi dana, persenjataan maupun pelatihanpelatihan secara rutin aparat militer yang melakukan pelanggaran $\mathrm{HAM}^{15}$

Di samping itu masalah tanggung jawab negara dalam hukum internasional klasik tidaklah dapat dilepaskan dari prinsip imunitas negara di forum nasional negara lain.Sebagai contoh dapat dikemukakan amatlah sulit meminta pertanggungjawaban negara berkaitan dengan pelanggaran HAM berat yang dilakukannya di forum nasional negara lain. Dalam kasus Al Adsani, seorang warga negara Inggris, terbukti tidak bisa meminta pertanggungjawaban negara Kuwait di pengadilan Inggris berkaitan dengan penganiayaan (torture) yang dilakukan aparat negara Kuwait terhadap dirinya ketika ia berada di Kuwait karena terhalang prinsip kedaulatan dan imunitas negara asing di pengadilan nasional. ${ }^{16}$

\section{Perkembangan hukum tanggung jawab}

negara dalam hukum lingkungan HAM, dan Investasi.

Ada beberapa perkembangan hukum tanggung jawab negara dalam primary rules yang dapat ditemukan, khususnya dalam hukum lingkungan internasional. Dalam kasus Chorfu Cannel, Mahkamah Internasional menetapkan... that one state has a duty not to cause harm in or to the territory of another state... Dalam kasus Trail Smelter 1941, negara dinyatakan melanggar hukum internasional ketika asap dan limbah dari pabriknya yang terletak di British Columbia menimbulkan kerusakan lingkungan di Amerika Serikai. Mahkamah Internasional menyatakan bahwa: ...under the principles of international law...no state has the right to use or permit the use of its territory in such a manner as to cause injury by fumes in or the terrotory of another or the properties or persons therein, when the case is of serious consequence and the injury is established by clear and convincing evidence...

Kasus di atas menjadi tonggak bahwa tanggung jawab negara terhadap kerusakan lingkungan tidak hanya sebatas di teritorialnya saja. Meskipun negara memiliki kedaulatan terhadap sumber daya alam yang ada di wilayahnya, juga terhadap segala aktifitas yang ada di wilayahnya, namun ia harus menjamin dan bertanggung jawab terhadap kerugian di wilayah tetangga yang diakibatkan semua aktifitas di teritorialnya.

Putusan di atas dipertegas lagi dalam Pasal

${ }^{i 5} / \mathrm{bid}$, sebagai contoh dapat dikemukakan

'Gihat kasus Al Adsani (berkewarganegaraan ganda, Inggris dan Kuwait) yang mengalami penolakan ketika akan mengajukan kasus dirinya yang disiksa oleh aparat Kuwait di Pengadilan Inggris yang dibenarkan oleh European Court on Human Right, Al-Adsani v United Kingdom, App. No.35763/97, paragraf 10, November, 21, 2001, htto://www.echr.coe.int/eng/judgments, htm 
22 Deklarasi Stockholm 1972 yang menetapkan bahwa States shall cooperate to develop further in the international law regarding liability and compensation for the victims of pollution and other environmental damage caused by activities within the jurisdiction or control of such States to areas beyond their jurisdiction

Perkembangan lain yang juga sangat menggembirakan adalah berkaitan dengan pengaturan ekspor limbah beracun. Ekspor limbah kimia beracun dan tergolong sangat berbahaya banyak dilakukan negara maju ke negara-negara miskin Asia dan Afrika. Pelaku ekspor tidak bisa dijerat oleh hukum nasional karena belum ada pengaturannya di tingkat nasional. Hal ini menjadi keprihatinan PBB yang selanjutnya berhasil mengeluarkan The Basel Convention on the control of Transboundary Movement of Hazardous Wastes and their disposal. Konvensi menyatakan bahwa tanggung jawab negara tidaklah hanya sebatas di teritorialnya saja. .Pembuatan konvensi ini semula mendapat tentangan keras karena dianggap melanggar kedaulatan baik negara penerima maupun negara pengirim. Sebagai kelanjutan dari Basle Convention beberapa perjanjian internasional antara lain antara Afrika dengan Masyarakat Eropa yang melarang ekspor limbah berbahaya antara negara-negara dari kedua benua. Tahun 1990 juga dibuat IAEA Code of Practice on the International Transboundary Movement of Radioactive Waste.

Contoh lain yang dapat dikemukakan adalah The North American Agreement on
Enviromental Cooperation 1993 yang memberikan hak pada NGO dan individu untuk mengadukan negara-negara pihak perjanjjan yang diduga gagal melaksanakan penegakan hukum lingkungan ke Komisi kerjasama lingkungan Amerika Utara. Individu dan nonstate entitiesyang perduli lingkungan juga dapat mengadukan pelanggaran lingkungan yang dilakukan negaranegara. pihak ke The Permanent Court of Arbitration (PCA). ${ }^{17}$.

Di tingkat nasional, pengadilan lingkungan di New Zealand juga di New South Wales, Australia memberikan kewenangan pada indjvidu untuk membawa kasus lingkungan ke depan pengadilan-pengadilan tersebut tanpa persyaratan personal injury. ${ }^{18}$

Di samping bidang hukum lingkungan kemajuan besar hukum tanggung jawab negara juga dapat ditemukan dalam hukum hak asasi manusia. Masalah pelanggaran HAM yang berat sebenarnya telah lama menjadi perhatian dunia internasional. ide dan pemikiran untuk mengadili para pelaku kekejaman dan pelanggaran HAM yang berat tersebut mengalami sejarah perkembangan yang cukup panjang. Ide dan pemikiran tersebut telah muncul dan, dikenal sejak jaman Yunani kuno, yaitu dengan terjadinya penuntutan terhadap para pelaku kekejaman dalam konilik bersenjata yang brutal, atas dasar standar nilai dan norma kemanusiaan yang bersumber pada filsafat dan agama. ${ }^{19}$

Pasca Perang dunia kedua terjadi ledakan berbagai instrumen HAM dan mekanismenya

\footnotetext{
${ }^{17}$ Edith Browns Weiss, opcit, hlm. 812

${ }^{18} /$ bid, hlm. 808

19Muladi, "Berbagai Dimensi Peradilan HAM, makalah pada Penataran Nasional Hukum Pidana dan Kriminologi", Kerjasama ASPEKUPIKI dan FH Ubaya, Surabaya, 14 Januari, 2002, hlm. 1, sebagaimana dikutip olet Supriyadi, "Pelanggaran HAM yang berat Dalam Perspektif Hukum Pidana Nasional dan Internasional", dalam jurnal Mimbar Hukum, No 43/11/2003, FHUGM, Yogyakarta, hlm. 21
} 
untuk melindungi individu-individu dari perlakuan kejam pemerintah mereka sendiri. Instrumeninstrumen HAM tersebut memasukkan beberapa pelanggaran HAM sebagai kejahatan (crimes) baik dalam hukum nasional maupun internasional dan terbuka kemungkinan terhadapnya diterapkan penegakan hukum transnasional (transnasional enforcement). ${ }^{20}$ Berdasarkan instrumen-instrumen HAM tersebut, khusus untuk pelanggaran berat HAM, pemaknaan prinsip legalitas tidak terbekap oleh ruang hukum yang sifatnya domestik, namun juga dapat bergerak leluasa dalam ruang hukum yang sifatnya internasional terhadap proses peradilan domestik. Ruang hukum domestik tidak menjadi satu-satunya ruang pergerakan ${ }^{21}$ untuk dijadikan landasan hukum guna mengadili pelaku delik pelanggaran berat HAM. Suatu perbuatan atau kelalaian yang diduga sebagai pelanggaran berat HAM yang belum diatur oleh hukum domestik tetap dapat dilakukan peradilannya dengan menggunakan institusi domestik, dengan mengacu pada norma hukum intemasional seperti statuta, yunisprudensi, konvensi, maupun kebiasaan internasional.

Dalam kaitannya dengan bahasan makalah ini, tanggung jawab negara dalam hukum hak asasi manusia internasional adalah berkaitan dengan kewajiban negara dalam memajukan dan melindungi hak asasi manusia yang diakui secara internasional. Tanggung jawab negara timbul, sebagai akibat dari pelanggaran hukum internasional oleh negara yaitu: ${ }^{22}$

a. melakukan tindakan pelanggaran hak asasi manusia (action), dan melalaikan, tidak melakukan tindakan apapun, atau melakukan pembiaran (ommision) terhadap pelanggaran hak asasi manusia.

b. Melakukan tindakan yang merupakan pelanggaran terhadap kewajiban internasional.

Tanggung jawab negara dalam pengertian ini juga merupakan bentuk pertanggung jawaban terhadap masyarakat internasional (erga omnes). Negara pelanggar hak asasi manusia tidak hanya bertanggung jawab terhadap negara-negara lain yang ikut andil dalam perjanjian hak asasi manusia multilateral tetapi juga bertanggung jawab secara langsung kepada indivudu atau kelompok yang dilanggar hak asasi manusianva dalam satu negara. Individu atau kelompok yang menjadi korban mempunyai hak untuk mengajukan tuntutan atas penderitaan yang dialaminya kepada negara dan atau kepada masyarakat internasional. ${ }^{23}$

Beberapa perjanjian internasional baik regional maupun internasional mengakui hak individu untuk complain terhadap pelanggaran hak asasi manusia yang dilakukan negaranya di depan pengadilan. Dalam keranǵka PBB dapat ditemukan 4 perjanjian internasional yaitu The First Optional Protokol to the International Covenant on Civil and Political Rights (ICCPR), The Optional Protokol to the Convention on the Elimination of All Forms of Discrimination Against Woman, The Convention Against Torture and Others Forms of Cruel and Inhuman Punishment, dan the International Convention on the Elimination of All Forms of Racial Discrimination yang memberikan hak-hak tersebut pada individu atau kelompok individu. ${ }^{24}$

\footnotetext{
${ }^{20}$ Mark Gibney, Katarina Tomasevski and Jens Vedsted-Hansen, op.cit, hlm.3

${ }^{21}$ A Irmanputra Sidin, "Asas Legalitas Peradilan HAM," Kompas, Senin'8 April 2002

${ }^{22}$ www.sekitarkita.com/glosarit.htm-9k

${ }^{23}$ Edith Browns Weiss, opcit, hlm, 808
} 
The First Optional Protokol to ICCPR serta The Optional Protokol to the Convention on the Elimination of All Forms of Discrimination Against Woman memberikan hak pada individu untuk membuat representation tertulis pada UN Human Right Committee terhadap pelanggaran Covenan oleh negara yang telah menerima covenant tersebut. Sejak awal 1977 sampai Agustus 2002, Komite telah mendaftar 1100 pengaduan menyangkut 70 negara. Fungsi komite adalah meningkatkan pengaduan ke proses adjudicating human right dispute. ${ }^{25}$

Di tingkat regional, individu juga diakui menjadi aktor penting yang dapat meminta pertanggung jawaban negara. European Court of Human Right di tahun 2001 menerima 31.393 pengaduan dari individu. Jumlah ini merupakna peningkatan bila dibandingkan tahun 1999 hanya 8400 kasus dan tahun 2000 dengan 10.482 kasus.

Di samping apa yang dikemukakan di atas bahwa negara bertanggung jawab pada individu yang dirugikan langsung, tanggung jawab negara terhadap masyarakat internasional (erga omnes) juga mengadung arti bahwa tanggung jawab negara tirdak hanya tertuju kepada negara yang dirugikan saja (injured state) tetapi seluruh masyarakat internasional.Putusan Mahkamah Internasional dalam kasus Barcelona sering dirujuk untuk memperkuat argumen tersebut: ${ }^{26}$

"....sangat penting untuk membedakan kewajiban negara terhadap masyarakat internasional sebagai keseluruhan, dan yang timbul dalam hubungan dengan negara lain di bidang perlindungan diplomatik. Menurut sifatnya, yang pertama merupakan kepentingan semua negara. Karena sifat hak-hak yang dilindungi dipandang penting, maka semua negara dapat dianggap mempunyai kepentingan hukum atas perlindungan hak-hak tersebut; kewajiban mereka disebut erga omnes. Kewajiban demikin berasal dari hukum internasional kontemporer, yang menyatakan tindakan agresi, genocide, perbudakan, dan diskriminasi rasial sebagai tindakan-tindakan di luar hukum. Beberapa hak yang dilindungi ini telah masuk hukum internasional umum, sedangkan yang lain dinyatakan oleh instrumen-instrumen sebagai mempunyai sifat quasi-universal atau universal. ${ }^{27}$

Sangat menarik juga kiranya untuk mengkaji putusan Pengadilan HAM Inter Amerika, yang menyatakan bahwa:

"...perjanjian HAM modern pada umumnya, Konvensi Amerika untuk HAM khususnya, bukanlah perjanjian multilateral tradisional yang dihasilkan dari saling memberi hak untuk kepentingan bersama negara pihak. Maksud dan tujuannya adalah untuk melindungi hak-hak dasar manusia, tanpa memandang kebangsaan, baik bagi warga negara pihak maupun terhadap negara pihak lainnya. Dalam menyimpulkan perjanjian-perjanjian HAM tersebut, negara dapat dikatakan telah menyerahkan diri

${ }^{24}$ ibid, hlm 809

${ }^{25} \mathrm{lbid}$

${ }^{26} \mathrm{Ibid}, \mathrm{hlm} .810$

${ }^{27}$ CJ Report dalam kasus Barcelona Traction Light Company (Tahap kedua, Belgia v Spanyol) tahun 1970, hlm.32, sebagaimana dikutip oleh lfdhal Kasim, "Prinsip-Prinsip Van Boven mengenai Korban Pelanggaran HAM", makalah pada Penataran Tingkat Advanced Hukum Humaniter Internasional dan HAM, kerjasama Unilak Riau dan ICRC, Pakanbaru, 2003 ibid, hlm.7 
mereka ke dalam suatu ketertiban hukum, dimana mereka telah menyanggupi melakukan berbagai kewajiban, bukan dalam hubungan ke negara lainnya, melainkan terhadap individu di dalam yurisdiksinya. ${ }^{28 .}$

Dari apa yang dipaparkan di atas nampak adanya pembedaan antara tanggung jawab negara terhadap masyarakat umum dalam kasus-kasus khusus seperti agresi, genocide, perbudakan, diskriminasi rasial serta pelanggaran HAM yang berat lainnya dan terhadap tanggung jawab negara lain dalam kasus-kasus umum hubungan bilateral mereka. Dalam kaitannya dengan pelanggaran HAM yang berat individu atau kelompok yang menjadi korban mempunyai hak untuk mengajukan kepada negaranya dan atau kepada masyarakat internasional tuntutan atas penderitaan yang dialaminya sebagai korban. Ini berarti bahwa sistem hukum nasional suatu negara harus memberikann prosedur-prosedur disipliner, administratif, perdata maupun pidana yang efektif sehingga memungkinkan korban mengakses ke sistem tersebut ${ }^{29}$

Di samping itu dapat dikemukakan pula bahwa berdasarkan konsep bahwa setiap negara punya kewajiban untuk menghormati hak-hak warganya sendiri dalam Gerakan HAM internasional, maka bangsa-bangsa lain serta masyarakat internasional punya hak dan tanggung jawab untuk menjatuhkan sanksisanksi jika kewajiban tersebut dilanggar.
Doktrin tradisional yang mengatakan bahwa tanggung jawab negara terbatas hanya pada warga negara asing di negara tersebut menjadi tak berlaku lagi. Karena perkembangan HAM internasional, tanggung jawab negara juga dapat muncul akibat perlakuan buruk pemerintah suatu negara terhadap warga negaranya sendiri. ${ }^{30}$

Perkembangan selanjutnya adalah dibidang hukum investasi. Perjanjian The International Centre for Settlement of Investment Dispute (ICSID) misalnya, memberikan hak pada investor asing, dalam hal ini adalah perusahaan transnasional maupun privat person yang merasa dirugikan oleh kebijakan House State untuk mengajukan sengketa penanaman modal asingnya pada ICSID secara langsung tanpa melalui negara asalnya. Sampai dengan tahun 2002 yang lalu lembaga ini sudah menerima 93 permintaan arbitase dan ${ }^{31} 3$ kasus untuk konsiliasi. Investor juga dapat mengajukan tuntutan ke pengadilan naisonal atau administrative tribunal terhadap perjnajian-perjanjian investasi bilateral. Sampai dengan Desember 2002, Amerika Serikat sudah menandatangani 45 perjanjian investasi bilateral, 37 diantaranya sudah berlaku yang mengijinkan investor individu menggunakan pengadilan atau administrasi tribunal pihak yang terlibat sengketa, mengajukan ke ICSID, atau arbitrase lain, dan memperoleh domestik interim injunctive relief selama proses arbitrase berlangsung. ${ }^{32}$

${ }^{28}$ Pengadilan Inter-Amerika Mengenai HAM, Seri A, Penilaian dan Pandangan, No.2 Paragraf 29, sebagaimana dikutip oleh lfdal Kasim, ibid

${ }^{29} /$ bid, hlm. 8

${ }^{30}$ Jemes Crawford, "The Relationship between Sanction and Countermeasures" dalam European Journal of International Law (EJIL) 2002, Vol. 13 No.3. hlm.667

${ }^{31}$ Andres Rigo, ICSID :An Overview, in Int'LARB . Rep, Winter, 2002(Fullbright \& Jaworski), sebagaimana dikutip oleh Edith Browns Weiss, opcit, him 813 


\section{Timbuinya Tanggung Jawab Negara menurut Draf ILC 2001}

Makalah ini sebagaimana dikemukakan pada bagian pendahuluan tidak bermaksud untuk membahas kapan dan syarat-syarat apa untuk timbulnya tanggung jawab negara dalam hukum internasional, tetapi hanya untuk membahas siapa yang memiliki hak (legal standing) menuntut negara yang melanggar kewajiban hukum internasional. Namun demikian secara sepintas akan dipaparkan bagaimana ILC mengatur mengenai kapan timbulnya tanggung jawab negara dalam hukum internasional.

Setiap internationally wrongful Acts negara menimbulkan tanggung. jawab negara. ${ }^{33}$ Tindakan berbuat atau tidak berbuat (omission) dari negara dapat merupakan Intemationally wrongful Acts yang mengandung dua unsur yaitu: ${ }^{34}$

a. dapat dilimpahkan pada negara berdasarkan hukum internasional

b. merupakan pelanggaran kewajiban terhadap hukum internasional (breach of an international obligation )

Karakterisasi tindakan negara yang menupakan Intemationally wrongful Acts diatur oleh hukum intemasional, tidak dipengaruhi oleh karakterisasi hukum nasional. ${ }^{35} \mathrm{Ada}$ pelanggaran terhadap kewajiban internasional bilamana tindakan negara tersebut tidak sesuai (not in con- formity) dengan yang disyaratkan terhadapnya oleh kewajiban tersebut, apapun sifat dan karakternya. ${ }^{36}$ Tindakan negara tidak merupakan pelanggaran kewajiban kecuali jika negara tersebut terikat oleh kewajiban yang dipermasalahkan pada saat tindakan terjadi. ${ }^{37}$

Unsur dapat dilimpahkan muncul karena dalam praktek negara tidak dapat bertindak sendiri, harus melalui individu sebagai organ negara, perwakilan negara atau pejabat negara. ${ }^{38}$ Tindakan negara yang dapat dilimpahkan adalah:

a. tindakan dari semua organ negara (state organ), baik legislatif, eksekutif, yudikatif atau apapun fungsinya, apapun posisinya dalam struktur organisasi negara dan apapun karakternya sebagai organ pemerintah pusat atau territorial unit dari suatu negara. Termasuk dlam organ adalah setiap orang atau kesatuan (entity) yang mempunyai status organ negara dalam hủkum nasiona $\left.\right|^{39}$

b. tindakan individu atau entity yang meskipun bukan organ negara atau diluar struktur formal pemerintah pusat atau daerah tetapi dikuasakan secara sah untuk melaksanakan unsur-unsur kekuasaan instansi tertentu pemerintah ${ }^{40}$

Tindakan organ negara atau orang atau kesatuan yang dikuasakan oleh elemen pemerintah sebagaimana dikemukakan di atas

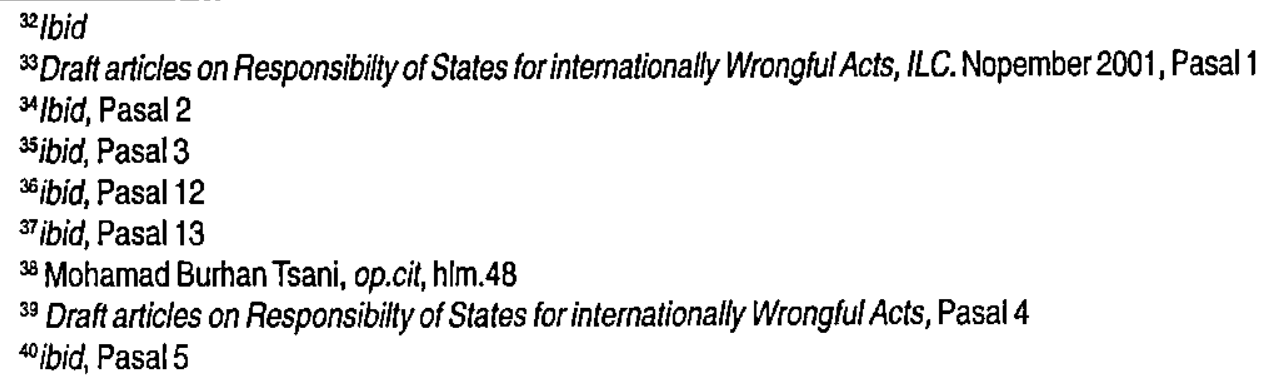


dalam kapasitas resminya dipandang sebagai tindakan negara dan dapat dilimpahkan ,bahkan jika mereka diluar kekuasaannya (exceeds its authority) atau melakukan tindakan yang bertentangan dengan instruksi yang diberikan padanya (contravention of instruction). ${ }^{41}$

Tindakan individu atau kelompok dianggap sebagai tindakan negara bilamana dalam melakukan tindakannya mereka mendapat instruksi, atau dibawah petunjuk atau kontrol negara ${ }^{42}$

Suatu negara yang membantu (aids or assist) negara lain dalam internationally wrongful Acts yang dilakukan negara lain tersebut bertanggung jawab secara internasional jika

A. that state does so with knowledge of the circumstances of the internationally wrongful Acts

B. the act would be internationally wrongful Acts if committed by that state

Suatu negara yang memberikan petunjuk atau mengontrol (direct or control) negara lain dalam melakukan internationally wrongful Acts bertanggung jawab secara internasional jika:

a. that state does so with knowledge of the circumstances of the internationally wrongful Acts

b. the act would be internationally wrongful Acts if committed by that state

Negara yang bertanggung jawab terhadap the internationally wrongful Acts wajib untuk:

a. cease that act, if it is continuing

b. offer apprppriate assurances and guarantiees of non-repetition, if circumstances so require.

Negara bertanggung jawab untuk memberikan full reparation terhadap kerugian (injury) yang ditimbulkan oleh the intemationally wrongful Acts. Kerugian yang dimaksud meliputi material, immaterial yang disebabkan oleh the internationally wrongful Acts negara tersebut. ${ }^{43}$

Full reparation terhadap kerugian yang disebabkan oleh the internationally wrongful Acts dapat dalam bentuk restitusi atau kompensasi atau pemuasan (satisfaction) atau kombinasi dari ketiganya.

Dari apa yang dipaparkan di atas nampak bahwa draft ILC 2001 menegaskan bahwa tanggung jawab negara timbul ketika ada tindakan atau kelalaian suatu negara yang merupakan pelanggaran kewajiban hukum internasional. Syarat berikutnya untuk timbul tanggung jawab negara adalah bahwa tindakan atau kelalaian tersebut di atas dapat dilimpahkan pada negara. Unsur adanya kerugian tidak lagi menjadi syarat mutlak untuk menuntut tanggung jawab suatu negara.

\section{Pemohon Tanggung Jawab Negara dalam "Draf ILC 2001}

Sebagaimana dikemukakan, Draf ILC 2001 tentang tanggung jawab negara (Draft articles on Responsibilty of States for internationally Wrongful Acts) banyak membawa perkembangan baru bagi hukum tanggung jawab negara dalam hukum internasional. Perkembangan baru ini khususnya menyangkut siapa yang dapat mengajukan tuntutan tanggung jawab negara.

Draft ILC 2001 tentang tanggung jawab negara terdiri dari 4 bagian dan 59 pasal. Bagian pertama tentang The Internationally

\footnotetext{
${ }^{41}$ ibid, Pasal 7

42 ibid, Pasal 8

${ }^{43}$ ibid, Pasal 36 dan 31
} 
wrongful act of a state, kedua tentang Content of the International Responsibilty of a State, ketiga tentang The implementation of the International Responsibilty of a State, dan keempat tentang General Provision.4

Salah satu perkembangan baru yang cukup banyak mendapat sorotan adalah menyangkut siapa yang dapat mengajukan tuntutan tanggung jawab negara yang diatur dalam bagian ketiga The implementation of the International Responsibilty of a State, khususnya dalam bab 1-nya tentang Invocation of the responsibilty of a State.

Bilamana hukum internasional klasik hanya memberikan hak pada negara yang dirugikan saja untuk menuntut tanggung jawab negara maka Draft ILC 2001 tentang tanggung jawab negara membedakan antara negara yang dirugikan (injured states) yang diatur dalam Pasal 42 dan negara yang tidak dirugikan (noninjured states).

Pasal 42 Draft selengkapnya menetapkan bahwa $A$ state is entitled as injured state to invoke the responsibility of another State if the obligation breached is owed to:

a. that state individually; or

b. a group of states including that State, or the international community as a whole, and the breach of the obligation:

1. specially affects that State or

2. Is of such a character as readilly to change the position of all the other States to which the obligation is owed with respect to the further performance of the obligation

Pasal 42 ini mirip dengan Pasal 60
Konvensi Wina 1969 tentang perjanjian internasional, berhubungan dengan material breaches of treaties. Pasal 42 paragraf a menetapkan bahwa suatu negara dirugikan ketika ada pelanggaran kewajiban individual. $\mathrm{Hal}$ ini dapat terjadi pada berbagai perjanjian bilateral, komitmen sepihak (unilateral commitment) seperti komitmen untuk tidak menggunakan jenis senjata tertentu, tidak mengambil ikan di zona tertentu, ketentuan umum hukum internasional yang melahirkan kewajiban tertentu antar dua negara seperti hubungan antara riparian state dalam international watercourse, atau juga perjanjian multilateral yang melahirkan kewajibankewajiban tertentu satu sama lain. 45

Adapun Paragraf $b$ diterapkan dalam hal suatu negara dipengaruhi oleh pelanggaran kewajiban hukum internasional oleh pihak lain. Contoh untuk kualifikasi ini adalah pelanggaran terhadap The Treaty on the Limited Test Ban Treaty atau The Prohibition on Sovereign Territorial Claims in the Treaty on Antartica ${ }^{46}$.

Dari apa yang dikemukakan di atas nampak bahwa pengertian injured state dalam Pasal 42 adalah pengertian yang sempit, tidak seluas pengertian dalam kasus Barcelona sebagaimana dikemukakan sebelumnya.

An Injured State yang meminta tanggung jawab dari negara lain memberitahukan tuntutannya pada negara tersebut supaya negara tersebut menghentikn tindakan pelanggarannya jika hal itu maish berlangsung. The Injured State juga dapat menyertakan dalam tuntutannya bentuk pemulthan (reparation) apa yang ia tuntut dari negara pelanggar. ${ }^{47}$

Tanggung jawab negara tidak dapat

${ }^{44}$ Lihat Draft articles on Responsibilty of States for internationally Wrongful Acts, ILC, 2001

${ }^{45}$ Edith Browns Weiss, opcit, hlm 802

${ }^{46} \mathrm{lbid}$ 
diminta jika: 48

a. the claim is not brought in accordance with any applicable rule relating to the nationality of claims

b. the claim is one to which the rule of exhaustion of local remedies applies and any available and effective local remedy has noot exhausted Tanggung jawab negara juga tidak dapat diminta jika:49

a. The injured state has validly waived the claim

b. The injured states is to be considered as having, by reason of its conduct, validly acquisced in the lapse of the claim

Selanjutnya, bila pasal 42 mengatur mengenai injured states maka Pasal 48 mengatur khusus mengenai invocation of responsibility by a state other than an injured state. Pasal 48 Draft menetapkan sebagai berikut:

1. Any State other than an injured State is entitled to invoke the responsibility of another State in accordance with paragraf 2 if:

a. the obligation breachedis owed to a group of States including that State is established for the protection of a collective interest of the group ; or

b. the obligation breached is owed to the international community as a whole

2. Any state enntitled to invoke responsibility under paragraf 1 may claim from the responnnsible State

a. Cessation of the intemationally wrongful act, and assumces and guarantees of non-repetition in accordance with article

\section{0; and}

b. Performance of the obligation of the reparation in accordance with the preceeding articles, in the interest of the injured State or the beneficiarie of the obligation breached

3. Therequirement for the invocation of responsibility by an injured State under articles 43,44 and 45 apply to an invocation of responsibility by a State entitled to do so undre paragraf 1

Berdasarkan Pasal 48 di atas negaranegara selain injured States dapat mengajukan tuntutan pertanggungjawaban pada negara lain dalam dua hal ${ }^{50}$ :

a. kewajiban yang dilanggar dimiliki suatu kelompok negara termasuk negara yang mengajukan tuntutan tersebut, ditetapkan untuk perlindungan kepentingan kelompok tersebut

b. kewajiban yang dilanggar dimiliki oleh seluruh masyarakat internasional keseluruhan

Bentuk yang pertama (a) mencakup perjanjian-perjanjian regional bidang keamanan, perlindungan $H A M$, dan lingkungan. $\mathrm{Hal}$ ini sesuai dengan tanggung jawab negara dalam S.S Wembledon case. Dalam kasus ini ketika Jerman menolak mengijinkan British Vessel yang disewa perusahaan Perancis untuk berlayar di The Kiel Canal, Inggris,Perancis, Italiy, dan Jepang menuntut Jerman untuk pelanggaran The Treaty of Verailles. Mahkamah Internasional Permanen mengakui hak (standing) ke-4 negara pemohon dengan dasar bahwa mereka

\footnotetext{
${ }^{47}$ Pasal 43 Draft ILC 2001

${ }^{49}$ Pasal 44 Drfat ILC 2001

${ }^{49}$ Pasal 45 Draft ILC 2001

${ }^{50} \mathrm{Jbid}, \mathrm{hlm} .803$
} 
mereka memiliki kepentingan hukum, sebagai negara pihak dalam Versailles treaty, memiliki kapal yang senantiasa melalui The Kiel $\mathrm{Ca}$ nal, meskipun Italy dan Jepang tidak memiliki kepentingan ekonomi langsung terhadap kasus ini. ${ }^{51}$

Hal yang paling menarik dan kontroversial dari pasal 48 draft adalah bentuk kedua (b), pelanggaran kewajiban yang dimiliki masyarakat internasional keseluruhan (erga omnes). Disini komisi penyusun draft merujuk pada putusan Mahkamah Internasional dalam kasus Barcelona yang membedakan antara kewajiban yang dimiliki negara tertentu dengan yang menyangkut masyarakat internasional keseluruhan. Dalam hal yang kedua ini masyarakat Internasional keseluruhan mempunyai hak (standing) mengajukan tuntutan terhadap negara pelanggar. Masuk kategori dimana masyarakat internasional mempunyai standing ini adalah kewajiban yang berkaitan dengan perlindungan HAM dan lingkungan. Contoh dibidang HAM antara lain masalah genocida, perbudakan, diskriminasi rasial ${ }^{52}$ dan self-determination. ${ }^{53}$ Adapun di bidang lingkungan adalah larangan to dispose high-or-medium level nuclear wastes di lautan. ${ }^{54}$

Hal yang penting dicermati menurut Edith Brown Weiss adalah bahwa Pasal 48 ditujukan pada international community as a whole bukan pada international community of states as a whole. Hal ini menunjukkan diterimanya pandangan bahwa masyarakat internasional tidak hanya terdiri dari negara. ${ }^{55}$

Pasal 48 (2) menetapkan bahwa setiap negara yang berhak untuk meminta pertanggungjawaban dari negara lain tidak hanya berhak meminta penghentian tindakan pelanggaran serta jaminan tidak mengulangi, tetapi juga berhak atas pemulihan kepentingan negara yang dirugikan atau beneficiaries dari kewajiban yang dilanggar.Tidak begitu jelas siapa yang dimaksud ILC dengan beneficiaries karena tidak ada penjelasan mengenai hal itu. Contoh beneficiaries yang sering dicontohkan para pakar adalah individu-individu yang mendapat keuntungan dari perjanjian HȦM. Ketidakjelasan ini tentu bisa mendatangkan permasalahan hukum ke depan bila penafsiran dilakukan terlalu luas, meskipun demikian ketentuan Pasal 48 ini diakui sebagai suatu proggressive development yang berani. ${ }^{56}$

Meskipun merupakan suatu kemajuan yang luar biasa dan perumusannya melalui perdebatan sengit, di sisi lain tidak berarti pasal tersebut tidak berbahaya. Bagaimanapun pasal tersebut berpotensi berbahaya karena tidak ada kejelasan atau kepastian mengenai pelanggaran apa saja yang memberikan hak pada masyarakat internasional keseluruhan untuk mengajukan tuntutan pertanggungjawaban. Draft menyerahkan pada masing-masing negara untuk menafsirkan apakah suatu pelanggaran kewajiban erga omnes sudah terjadi atau tidak. Hal ini menurut D.N Hutchinson dapat menimbulkan bahaya yaitu bahwa hak yang

\footnotetext{
${ }^{51} /$ bid.

52/bid, hlm. 804

${ }^{59}$ East Timor case (Portugal v Australia) , 1995 ICJ Report. 90, 102 paragraf 29. Dalam putusan ini Self determination dinyatakan sebagai erga omnes obligation

${ }^{54}$ Edith Browns Weiss, loc.cit

${ }^{55} \mathrm{bid}$

${ }^{56} \mathrm{lbid}$, hlm. 805
} 
diberikan Pasal 48 (1) tersebut disalahgunakan untuk menjustifikasi tindakan-tindakan yang bermotivasi politik atau intervensi unilateral oleh suatu negara terhadap negara lain dengan dalih untuk menegakkan hukum internasional. ${ }^{57}$

Untuk mencegah kemungkinan yang dikhawatirkan oleh D.N Hutchinson, suatu negara ditundukkan dengan pembalasan (counter measures) berdasarkan tuntutan hukum yang curang (spurious legal claim) pasal 48(1) harus dibaca keseluruhan dengan pasal-pasal mengenai countermeasures, pasal 49-54. Pasal 49 menetapkan bahwa countermeasure hanya dapat dilakukan oleh suatu negara terhadap negara yang melakukan internationally wrongful act untuk memaksa negara tersebut melaksanakan kewajbannya. ${ }^{58}$ Countermeasures tidak mempengaruhi kewajiban negara untuk menahan diri dari ancaman atau penggunaan kekerasan (use of force) dalam Piagam PBB , kewajiban perlindungan HAM yang fundamental, kewajiban a humanitarian character prohibiting reprisals, dan kewajiabn lain dibawah premptory norms of general internasional law. ${ }^{59}$ Countermeasures yang dilakukan suatu negara terhadap negara yang lain juga harus tetap menghormati prinsip tidak dapat diganggu gugatnya (inviolabilty) agenagen diplomatik dan konsuler, gedung-gedung (premises), arsip serta dokumen perwakilan asing. ${ }^{60}$ Countermeasures juga harus dilakukan secara proporsional sesuai dengan kerugian yang diderita dan bobot pelanggaran kewajiban yang dipermasalahkan. ${ }^{61}$ Countermeasures harus dihentikan sesegera mungkin setelah negara pelanggar melaksanakan kewajibannya. ${ }^{62}$ Selanjutnya yang juga sangat penting adalah bahwa Pasal 54 membatasi hak negaranegara yang berhak meminta pertanggung jawaban negara lain berdasarkan Pasal 48 (1) dengan lawful measures. ${ }^{63}$

Perdebatan mungkin tidaknya aktor nonnegara meminta tanggung jawab negara sangatlah sengit dalam proses penyusunan draft. Sebagian anggota komisi menghendaki bahwa hak non-state actor dinyatakan tegas dan diatur rinci sementara yang lain menolak.Akhirnya kompromi atau pendekatan yang digunakan oleh ILC adalah dengan mengingatkan pada semuanya bahwa Draft ILC merupakan secondary rules, mengatur masalah tanggung jawab negara secara umum dan tidak menutup kemungkinan adanya aturan khusus tanggung jawab negara dibidang-bidang tertentu. Hal ini ditegaskan dalam Pasal 33 bahwa:

1. The obligation of the responsible State set out in this part may be owed to another state, to several states, or to the international community as awhole, depending in par-

${ }^{57}$ D.N Hutchinson, "Solidarity and Breaches of Multilateral Treaties", 1988, Britania Year Book International Law. 152, 202, sebagaimana dikutip oleh Edith Browns Weiss, ibid

${ }^{59}$ Pasal 49(1) Draf ILC 2001

${ }^{59}$ Pasal 50 (1) Draf ILC 2001

${ }^{60}$ Pasal 50 (2b) Draf ILC 2001

${ }^{61}$ Pasal 51 Draf ILC 2001

${ }^{62}$ Pasal 53 Draf ILC 2001

${ }^{63} \mathrm{Pasal} 54$ draft selengkapnya berbunyi this chapter does not prejudice the right of any State, entitled under article 48, paragraph 1 to invoke the responsibility of another state, to take lawful measures against that state to ensure cessation of the breach and reparation in the interest of the injured state to ensure 
ticular on the character and the content of the international obligation and on the circumstances of the breach

2. this part is without prejudice to any right, anising from the international responsibility of a State, which may accrue directly to any person or entity other than State

Demikianlah draft mengakui bahwa the primary rules dapat menetapkan siapa yang dapat minta tanggung jawab negara. Draf tidak menunjuk aktor siapa dan untuk kewajiban apa aktor non-negara dapat mengajukan tuntutan. Draf menyerahkan hal ini pada the primary rules sebagai lex specialis. Dengan demikian sangat dimungkinkan dalam beberapa prosedur suatu entity meminta tanggung jawab negara secara langsung tanpa melalui intermediation negara manapun. Hal ini sesuai dengan perkembangan yang terjadi di perjanjian-perjanjian internasional maupun regional tentang HAM, lingkungan, juga perjanjian perlindungan investor asing. Dapat disimpulkan bahwa pada prinsipnya Draft ILC hanya mengatur prinsip-prinsip umum tanggung jawab negara, tidakmengatur topik-topiktertentu secara khusus ${ }^{64}$

Masalah lex specialis dipertegas lagi oleh ILC dalam Pasal 55 tentang lex specialis yang menetapkan bahwa ...these articles do not apply where and to the extent that the conditions for the existence of an intemationally wrongful act or the content or the implementation of the international responsibility of a State are govemed by special rules of intemational law.

\section{Penutup}

Draft articles on Responsibilty of States for internationally Wrongful Acts ILC membawa beberapa perkembangan baru yang penting. Salah satu perkembangan baru tersebut adalah menyakut siapa yang berhak mengajukan tuntutan (invoke) pada negara lain dalam hal terjadinya pelanggaran kewajban intemasional. Bila hukum internasional klasik hanya mengakui negara yang dirugikan langsunglah sebagai pihak yang dapat mengajukan tuntutan,maka draft ILC 2001 memungkinkan negara yang tidak dirugikan untuk mengajukan tuntutan yaitu dalam hal pelanggaran kewajiban yang dimiliki oleh masyarakat internasioanal keseluruhan (erga omnes). Dengan demikian masalah pelanggaran HAM berat yang terjadi di suatu negara dan selama ini dipandang masalah domestik semata dan negara lain tidak memiliki legal standing tidaklah berlaku lagi. Draf ILC dengan segala kekurangannya menetapkan dirinya sebagai secondary rules, memungkinkan keberadaan primary rules sebagai lex specialis mengatur hal-hal yang belum diatur oleh Draf seperti halnya menyangkut aktor non negara dan pelanggaran kewajiabn apa saja yang diklaim sebagai milik masyarakat internasional keseluruhan.

\section{Daftar Pustaka}

Dixon, Martin, Textbook on International Law, Blackstone Press Limited, Fourt Edition, 2000

Huala Adolf,Aspek-Aspek Negara Dalam Hukum Internasional, Rajawali Pers, Jakarta, Cetakan Pertama, 1991

Mohamad Burhan Tsani, Hukum dan Hubungan Intemasional, Liberty, Yogyakarta, Cetakan

${ }^{64}$ Dixon, Martin, op.cit, hlm.230 
Pertama, 1990

Shaw, M.N, Intemational Law, Grotius Publication, third edition, 1991

\section{Makalah/Artikel}

Daniel Bodansky and John R Crook, "Symposium The ILC'S State Responsibility Article ;Introduction and Overview", dalam American Journal of International Law (AJIL), Vol 96, 2002

Edith Browns Weiss," Invoking State Responsibilty in the Twenty-First Centuries", dalam American Journal of International Law (AJIL), Vol. 96, 2002

Georg Nolte, "From Dioniso Anzillotti to Roberto Ago: The Classical Intemational Law of State Responsibility and the Traditional Primacy of a Bilateral Conception of Inter-state Relations", dalam European Journal of Intemational Law (EJIL) 2002, Vol. 13 No. 5

Ifdhal Kasim, "Prinsip-Prinsip Van Boven mengenai Korban Pelanggaran HAM", makalah pada Penataran Tingkat Advanced Hukum Humaniter Internasional dan HAM, kerjasama Unilak Riau dan ICRC, Pakanbaru, 2003

Irmanputra Sidin, "Asas Legalitas Peradilan

HAM," dalam harian Kompas, Senin 8 April 2002

James Crawford, "The Relationship between Sanction and Countermeasures" dalam European Journal of International Law (EJIL) 2002, Vol. 13 No.3.
Mark Gibney, Katarina Tomasevski and Jens Vedsted-Hansen, "Transnasional State Responsibility for Violation of Human Rights, dalam Harvard Human Rights Journal, Vol 12, Spring 1999

Mohamad Mova Al'Afghani, 'Kewajiban Swedia untuk melakukan due Diligence Terhadap permasalahan Hasan Tiro", makalah pada workshop on International Legal Process, Hotel Ibis ,25-26 Juli 2003, http//www.theceli.com/berita/ detailphp?tipe=a\&news=B2, diakses 5 Maret 2004

Supriyadi, "Pelanggaran HAM yang berat Dalam Perspektif Hukum Pidana. Nasional dan Internasional", dalam jurnal Mimbar Hukum, No 43/11/2003, FH UGM , Yogyakarta

www.sekitarkita.com/glosari/t.htm-9k

\section{Dokumen}

Draft articles on Responsibilty of States for internationally Wrongful Acts , ILC, November 2001

\section{Putusan Pengadilan}

European Court on Human Right, Àl-Adsani v United Kingdom, App. No.35763/97, paragraf 10, November, 21, 2001, http:l Lwww.echr.coe.int/eng/judgments, $\mathrm{htm}$

East Timor case (Portugal v Australia), 1995 ICJ Report. 